\title{
Model Spasial Level Dasar Bangunan Kota Tepian Air (Studi Kasus: Kota Makassar)
}

\author{
Spatial Model of Building Ground Level for Waterfront City \\ (Case Study: Makassar City)
}

\section{Sudirman Nganro ${ }^{1}$, Slamet Trisutomo ${ }^{2}$, Roland A. Barkey ${ }^{3}$, Mukti Ali ${ }^{2}$, Nurjannah Nurdin ${ }^{4}$}

\begin{abstract}
Abstrak: Banjir adalah ancaman bagi kota pantai seperti Kota Makassar. Untuk menghindari ancaman banjir, diperlukan penentuan level dasar bangunan. Penelitian ini bertujuan untuk menyusun model spasial penentuan level dasar bangunan untuk Kota Makassar berbasis data perubahan iklim dan geografi lingkungan. Prediksi kenaikan muka air laut menggunakan aplikasi MAGICC/SCENGEN, analisis citra satelit berbasis SIG, analisis curah hujan menggunakan metode poligon Thiessen, nilai koefisien limpasan permukaan ditentukan dengan metode Cook, dan analisis debit banjir rancangan dengan metode HSS Nakayasu. Model spasial level dasar bangunan Kota Makassar untuk tahun 2030 adalah fungsi dari pasang air laut, kenaikan muka air laut karena perubahan iklim, banjir alluvial dan banjir kiriman yang dapat terjadi secara bersamaan. Model tersebut menghasilkan peta spasial dengan atribut koordinat geografi $(\mathrm{x}, \mathrm{y}, \mathrm{z})$.
\end{abstract}

Kata kunci: Model spasial, level dasar bangunan, perubahan iklim, geografi lingkungan, Kota Makassar

\begin{abstract}
Flooding is a threat to coastal cities such as Makassar City. To Avoid the threat of flooding, it is necessary to determine the ground level of the building. This study aims to develop a spatial model for determining the ground level of buildings for Makassar City based on climate change data and environmental geography. Prediction of sea level rise using MAGICC/SCENGEN application, GIS-based satellite image analysis, rainfall analysis using Thiessen polygon method, surface runoff coefficient value determined by Cook method, and design flood discharge analysis with HSU Nakayasu method. The spatial model of the ground level of Makassar City building for 2030 is a function of sea tides, sea level rise due to climate change, alluvial floods and inflow floods that can occur simultaneously. The model produces a spatial map with attributes of geographic coordinates $(\mathrm{x}, \mathrm{y}, \mathrm{z})$.
\end{abstract}

Keyword: spatial models, building ground level, climate change, environmental geography, Makassar city

\section{PENDAHULUAN}

Banjir di Kota Makassar menyebabkan rumah tinggal dan prasarana jalan rusak akibat genangan air, sehingga diperlukan model spasial berupa peta yang beratribut koordinat geografi $\mathrm{x}, \mathrm{y}, \mathrm{z}$ dalam penentuan level dasar bangunan (peil). Dalam proses desain dan

\footnotetext{
${ }^{1}$ Departemen Arsitektur, Fakultas Teknik, Universitas Hasanuddin

${ }^{2}$ Lab. Pengembangan Kawasan Tepian Air, Fakultas Teknik, Universitas Hasanuddin

${ }^{3}$ Lab. Perencanaan dan Sistem Informasi Kehutanan, Fakultas Kehutanan, Universitas Hasanuddin

${ }^{4}$ Puslitbang Laut, Pesisir dan Pulau-Pulau Kecil, Universitas Hasanuddin
} 
pelaksanaan (pemasangan boplang) pembangunan rumah tinggal, ditentukan ketinggian (peil) $\pm 50 \mathrm{~cm}$ dari permukaan tanah (Frick, 1980). Proses penentuan seharusnya merujuk pada suatu model spasial berupa peta untuk menjamin bangunan aman dari banjir.

Model spasial level dasar bangunan dapat disusun dengan mempertimbangkan aspek yang menyebabkan banjir yaitu aspek perubahan iklim yang meliputi faktor kenaikan muka air laut, curah hujan, pasang air laut dan banjir kiriman, sedangkan aspek geografi lingkungan meliputi faktor penggunaan lahan dan tutupan lahan, luas daerah aliran sungai (DAS), kontur dan jenis tanah (Rachmat, 2014; Sudirman, Trisutomo, 2017; Welde, 2017).

Perubahan iklim muncul sebagai sebuah fenomena sejak awal abad ke-19 (Ghoneem, 2016) yang merupakan dampak dari pemanasan global yang menyebabkan kenaikan suhu, pencairan es dan gletser, kenaikan muka air laut, serta kerusakan-kerusakan ekologi makhluk hidup (Vellinga, 1993; Kodoatie, 2010; Imaduddina, 2014; Suhelmi, 2014).

Daerah aliran sungai (DAS) yang berdampak banjir di Kota Makassar meliputi DAS Jeneberang dan DAS Tallo (Sudirman, Trisutomo, 2018). Hujan yang jatuh pada daerah aliran sungai akan berubah menjadi aliran permukaan (Triatmodjo, 2008; Shrestha, Lohpaisankrit, 2016). Salah satu faktor yang mempengaruhi limpasan permukaan adalah kondisi penggunaan lahan (Takeda, 1983; Pudjiharta, 2008). Perubahan penggunaan lahan di perkotaan disebabkan oleh urbanisasi (Surya, 2015; Gaitan, Giesen, 2016).

Sejauh penelusuran pustaka yang dilakukan, ada 3 (tiga) kelompok besar penelitian yang terkait dengan tujuan penelitian. Pada Gambar 1 ditunjukkan beberapa nama peneliti dan variabel yang diukur dalam mengkaji masalah banjir di kota-kota pantai. Metode yang digunakan dan variabel yang diukur masing-masing memperlihatkan perbedaan. Ketiga kelompok yang dimaksud adalah :

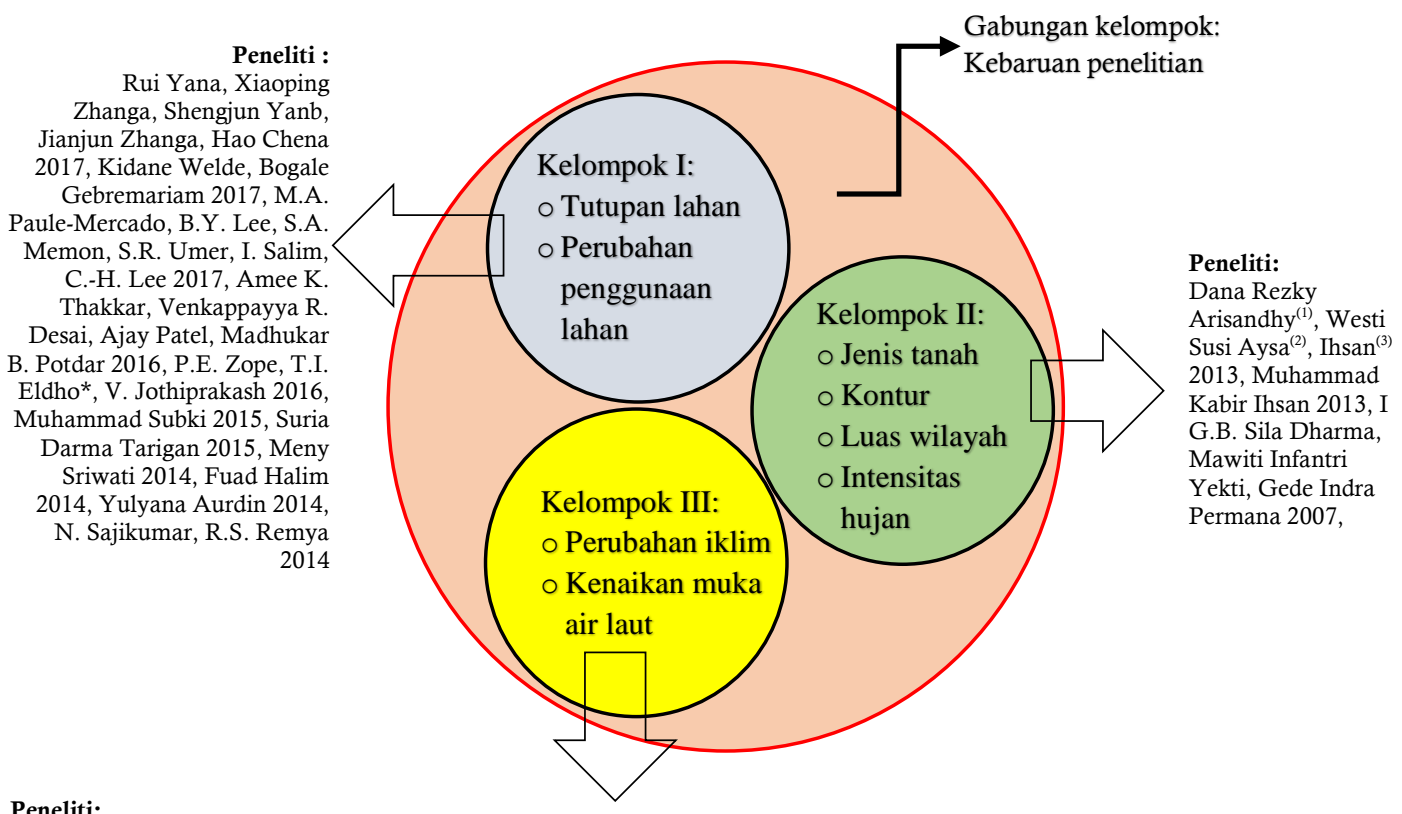

Peneliti:

S. Gaitan*, N.C. van de Giesen, J.A.E. ten Veldhuis 2016, Shimon Wdowinski, Ronald Bray, Ben P. Kirtman, Zhaohua Wu 2016, Ozgun Ozsoy, Ivan D.Haigh, Matthew P.Wadey, Robert J. Nicholls, Neil C. Wells 2016, Kania Dewi Nastiti*, Yeonsu Kimª Kwansue Junga,

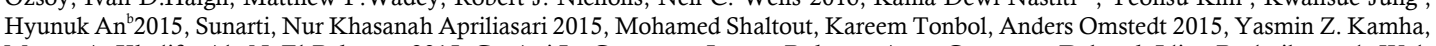
Marwa A. Khalifa, Aly N. El-Bahrawy 2015, Gon'eri Le Cozannet, Jeremy Rohmer, Anny Cazenave, Deborah Idier, Roderik van de Wal, Renske de Winter, Rodrigo Pedreros, Yann Balouin, Charlotte Vinchon, Carlos Oliveros 2015, Hugh Brammer ${ }^{1} 2014$, Ifan R. Suhelmi* dan Hari Prihatno 2014, Chang-lin CHEN, Jun-cheng ZUO, Mei-xiang CHEN, Zhi-gang GAO, C.-K. SHUM 2014, Armi Susandi, Indriani Herlianti,Mamad Tamamadin, Irma Nurlela 2008.

Gambar 1. Kelompok Peneliti 
Kelompok pertama yang meliputi tutupan lahan dan perubahan penggunaan lahan adalah kelompok (Yana, Zhanga, Yanb, Zhanga, Chena; Welde, Gebremariam; PauleMercado, Lee, Memon, Umer, Salima, Lee, 2017), (Zope, Eldho dan Jothiprakash; Thakkar, Desai, Patel, Potdar 2016), (Nastiti; Kim, Jung, An; Subki; Tarigan, 2015), (Sriwati; Halim; Aurdin; Sajikumar, Remya, 2014), (Ihsan, 2013), (Dharma, Yekti, Permana, 2007), mengungkap bahwa genangan banjir disebabkan oleh perubahan penggunaan lahan dan tutupan lahan sehingga limpasan permukaan meningkat pada saat hujan turun.

Kelompok kedua yang meliputi jenis tanah, kontur, luas wilayah dan intensitas hujan adalah (Gaitan, Giesen, Veldhuis, 2016), (Arisandhy, Aysa, Ihsan, 2013), mengungkap bahwa genangan banjir disebabkan oleh penggunaan lahan dan tutupan lahan, jenis tanah, kontur, kemiringan lereng, luas daerah aliran sungai (DAS), intensitas hujan. Kelompok ini lebih ke geografi lingkungan dan spesifik dibandingkan dengan kelompok pertama, spesifikasi dapat dicermati dengan melihat variabel yang diukur lebih variatif seperti pemisahan variabel penggunaan lahan dan tutupan lahan dengan jenis tanah.

Kelompok ketiga yang meliputi perubahan iklim dan kenaikan muka air laut adalah kelompok (Wdowinski, Bray, Kirtman, Wu; Ozsoy, Haigh, Wadey, Nicholls, Wells, 2016), (Sunarti, Apriliasari; Shaltout, Tonbol, Omstedt; Kamha, Khalifa, El-Bahrawy; Cozannet, Rohmer, Cazenave, Idier, Wal, Winter, Pedreros, Balouin, Vinchon, Oliveros, 2015), (Hugh Brammer; Chen, Zuo, Chen, Gao, Shum; Suhelmi, Prihatno, 2014), (Susandi, Herlianti, Tamamadin, Nurlela, 2008), mengungkap bahwa genangan banjir disebabkan oleh kenaikan muka air laut.

Penelitian oleh ketiga kelompok tersebut masih bersifat parsial-parsial sehingga peneliti berpandangan bahwa hasil yang diperoleh belum optimal untuk menentukan tinggi muka air banjir yg optimum sebagai dasar untuk menentukan level dasar bangunan. Penelitian ini bertujuan untuk mengintegrasikan variable-variabel tersebut dalam menyusun model spasial level dasar bangunan Kota Makassar yang berfungsi sebagai instrumen spasial untuk menentukan peil bangunan yang aman dari banjir.

\section{METODE}

\section{Objek Penelitian}

Kecamatan Pesisir Kota Makassar sepanjang garis pantai meliputi Kecamatan Biringkanaya, Tamalanrea, Tallo, Ujung Tanah, Wajo, Ujung Pandang, Mariso, dan Tamalate, ditunjukkan pada Gambar 2.

\section{Aspek Perubahan Iklim}

Unsur perubahan iklim dalam penelitian ini adalah kenaikan muka air laut global diprediksi dengan aplikasi MAGICC/SCENGEN (Raharjo, 2011; Joesidawati, 2006; NgoDuc, 2014). Pasang surut adalah fluktuasi muka air laut karena adanya gaya tarik bendabenda di langit, terutama matahari dan bulan terhadap massa air laut di bumi (Sutirto, 2014). Data pasang air laut Kota Makassar menggunakan data BIG (badan informasi geospasial). Data curah hujan (2000-2014) bersumber dari global weather, dianalisis dengan metode polygon Thiessen (Triatmodjo, 2013) menggunakan aplikasi SIG. Debit banjir rancangan $(\mathrm{T}=20)$ dianalisis dengan metode HSS Nakayasu (Dewi, Limantara, 2016; Qoriaulfa, Putri, 2016). Data banjir kiriman bersumber dari hasil penelitian Pusat Pengendalian Pembangunan Ekoregion Sulawesi dan Maluku "Ketersediaan Air dan Arahan Pengendalian Pembangunan di Kawasan Strategis Nasional MAMMINASATA" (Darhamsyah, 2015). 


\section{Aspek Geografi Lingkungan}

Unsur geografi lingkungan yang meliputi penggunaan lahan dan tutupan lahan (Aurdin, 2014; Dewi, Limantara, 2016), dan identifikasi daerah aliran sungai (DAS) yang berdampak banjir pada objek penelitian menggunakan teknik analisis citra berbasis SIG. Penentuan koefisien limpasan permukaan pada objek penelitian menggunakan metode Cook ( Wahyuningrum, 2007; Samaawa, 2016 ), nilai koefisien limpasan permukaan adalah salah satu parameter untuk menghitung debit banjir dengan metode HSS Nakayasu (Subarkah, 1980; Nganro, Trisutomo, 2019).

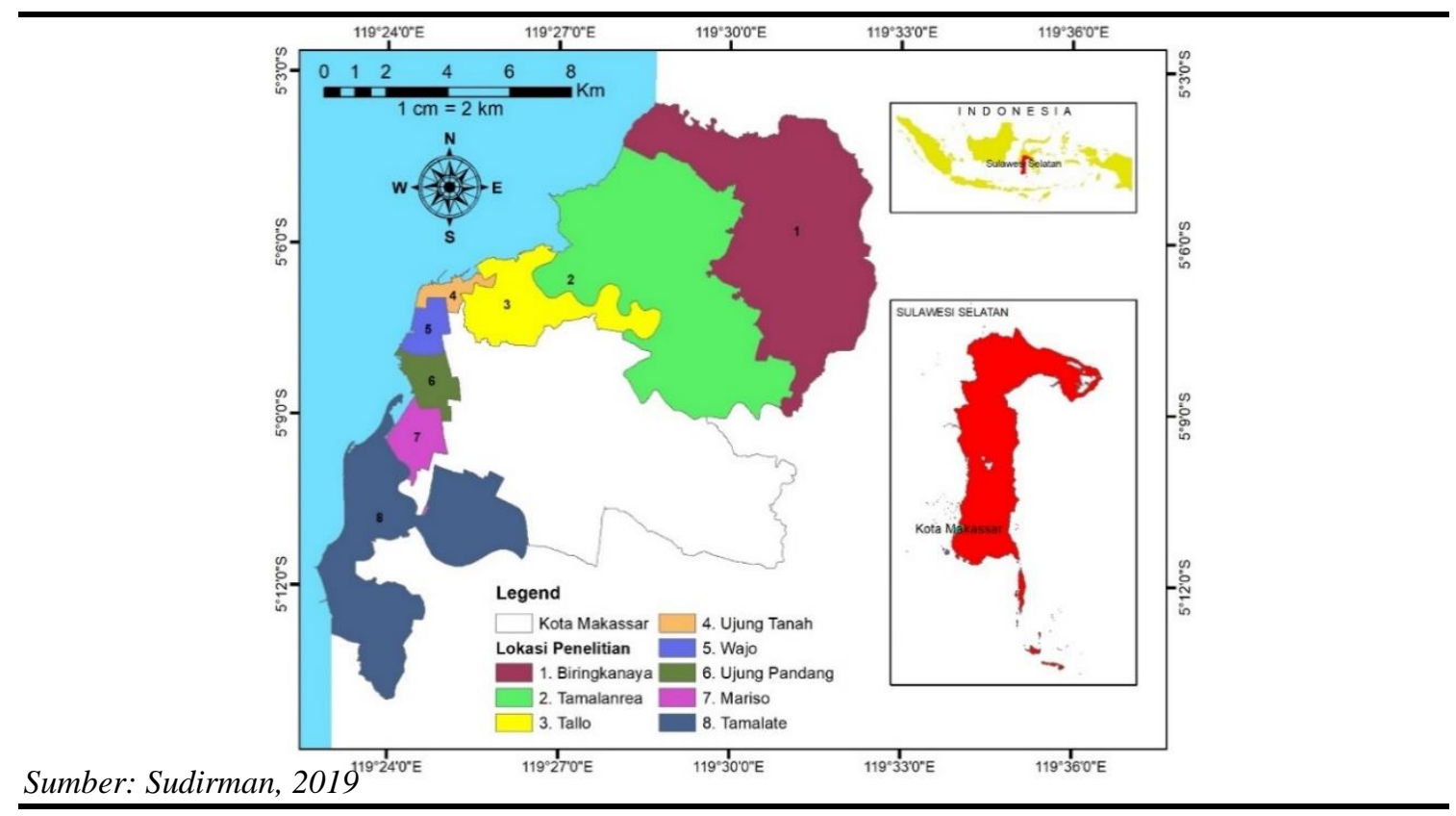

\section{Gambar 2. Objek Penelitian}

\section{HASIL DAN PEMBAHASAN}

Model spasial level dasar bangunan di Kota Makassar disusun dengan kombinasi data kenaikan muka air global, pasang air laut, debit banjir pada objek penelitian dan banjir kiriman, yang terjadi secara bersamaan. Hasil analisis menunjukkan bahwa:

\section{Kenaikan Muka Air Laut Global}

Analisis kenaikan muka air laut menggunakan aplikasi MAGICC/SCENGEN dengan skenario CSIRO. Hasil analisis menunjukkan bahwa kenaikan muka laut dengan parameter A1B-AIM adalah yang terbesar yaitu $6,257 \mathrm{~cm}$. Data ditunjukkan pada Tabel 1.

Tabel 1. Kenaikan Muka Air Laut, 2008-2030

\begin{tabular}{ccccc}
\hline Tahun & $\begin{array}{c}\text { Referensi pengguna } \\
\text { A2-AIM } \\
\text { KML }(\mathrm{cm})\end{array}$ & $\begin{array}{c}\text { Kebijakan pengguna } \\
\text { A1B-AIM } \\
\text { KML }(\mathrm{cm})\end{array}$ & $\begin{array}{c}\text { Referensi standar } \\
\text { A2-AIM } \\
\text { KML (cm) }\end{array}$ & $\begin{array}{c}\text { Kebijakan standar } \\
\text { A1B-AIM } \\
\text { KML (cm) }\end{array}$ \\
\hline 1990 & 5,739 & 5,739 & 5,933 & 5,933 \\
2008 & 0,000 & 0,000 & 0,000 & 0,000 \\
2010 & 0,461 & 0,471 & 0,442 & 0,452 \\
2015 & 1,665 & 1,726 & 1,596 & 1,659 \\
2020 & 2,926 & 3,088 & 2,807 & 2,972 \\
2025 & 4,231 & 4,589 & 4,062 & 4,424 \\
2030 & 5,588 & 6,257 & 5,369 & 6,042 \\
\hline
\end{tabular}




\section{Pasang Air Laut}

Data pasang air laut Kota Makassar periode Tahun 2008-2030 diperoleh dari situs http://tides.big.go.id/, diakses pada 9 April 2018 pukul 16:17:46 sore. Data yang digunakan dalam proses pemodelan adalah nilai pasang air laut tertinggi yaitu $0,560 \mathrm{~m}$. seperti diinformasikan pada Tabel 2.

Tabel 2. Data Pasang Air Laut Kota Makassar

\begin{tabular}{cccc}
\hline \multirow{2}{*}{ Tahun } & Tinggi Pasang Maks $(\mathrm{m})$ & Tanggal & Waktu \\
& & $15 / 11 / 2008$ & Jam \\
\hline 2008 & 0,547 & $05 / 11 / 2009$ & 10.00 .00 \\
2009 & 0,518 & $16 / 05 / 2010$ & 23.00 .00 \\
2010 & 0,493 & $29 / 10 / 2011$ & 10.00 .00 \\
2011 & 0,501 & $16 / 11 / 2012$ & 10.00 .00 \\
2012 & 0,501 & $06 / 11 / 2013$ & 10.00 .00 \\
2013 & 0,484 & $25 / 11 / 2014$ & 10.00 .00 \\
2014 & 0,472 & $31 / 10 / 2015$ & 11.00 .00 \\
2015 & 0,466 & $17 / 11 / 2016$ & 10.00 .00 \\
2016 & 0,496 & $06 / 12 / 2017$ & 10.00 .00 \\
2017 & 0,503 & $26 / 11 / 2018$ & 11.00 .00 \\
2018 & 0,510 & $15 / 12 / 2019$ & 11.00 .00 \\
2019 & 0,503 & $18 / 11 / 2020$ & 10.00 .00 \\
2020 & 0,533 & $08 / 11 / 2021$ & 11.00 .00 \\
2021 & 0,553 & $26 / 11 / 2022$ & 10.00 .00 \\
2022 & 0,556 & $08 / 05 / 2023$ & 23.00 .00 \\
2023 & 0,534 & $18 / 11 / 2024$ & 10.00 .00 \\
2024 & 0,545 & $08 / 11 / 2025$ & 10.00 .00 \\
2025 & 0,560 & $18 / 05 / 2026$ & 22.00 .00 \\
2026 & 0,544 & $08 / 05 / 2027$ & 22.00 .00 \\
2027 & 0,525 & $21 / 10 / 2028$ & 10.00 .00 \\
2028 & 0,503 & $08 / 11 / 2029$ & 10.00 .00 \\
2029 & 0,515 & $27 / 11 / 2030$ & 10.00 .00 \\
2030 & 0,501 & & \\
\hline
\end{tabular}

Sumber: Situs BIG

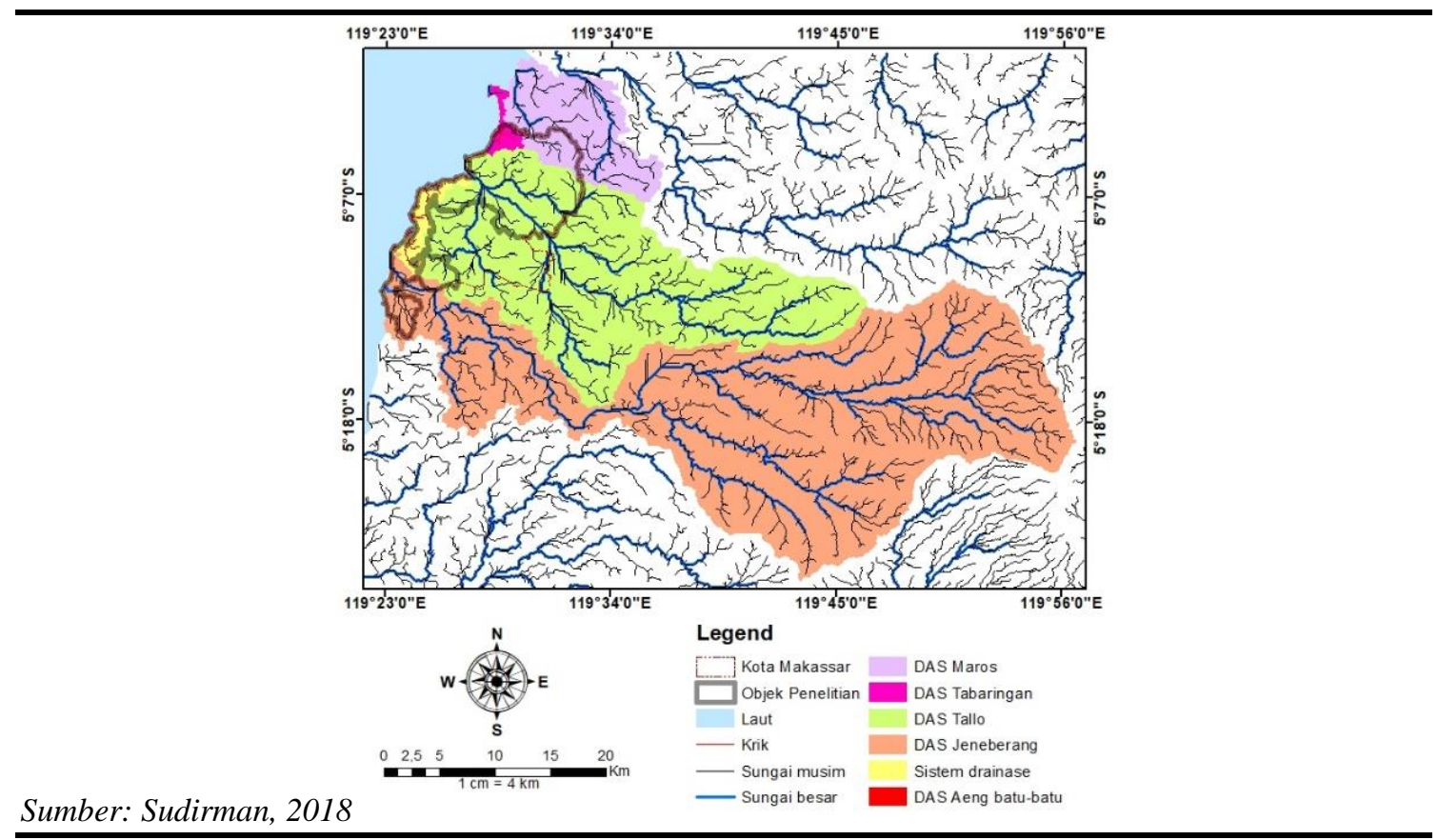

Gambar 3. Daerah Aliran Sungai (DAS) 


\section{Banjir Aluvial dan Banjir Kiriman}

Analisis debit banjir pada suatu daerah aliran sungai (DAS) dilakukan dengan metode HSS Nakayasu (Fachri, 2017). Identifikasi terhadap daerah aliran sungai (DAS) yang berdampak banjir pada objek penelitian ditunjukkan pada Gambar 3.

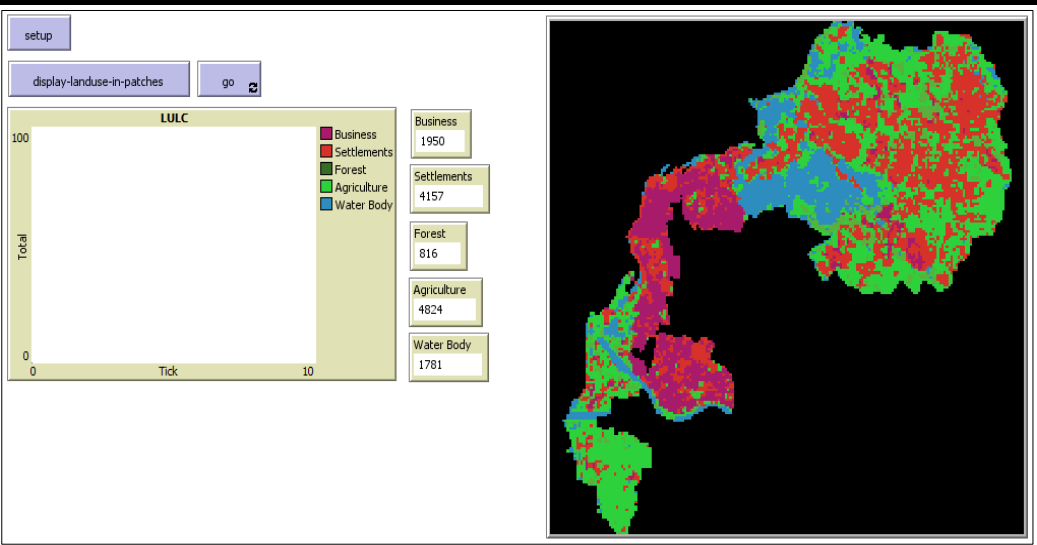

Sumber: Sudirman, 2019

Gambar 4. Peta Penggunaan Lahan dan Tutupan Lahan, 2017

Berdasarkan analisis dengan metode Cook, nilai koefisien limpasan permukaan objek penelitian diperoleh sebesar 0,4734 (Nganro, Trisutomo, 2019).

Hasil analisis debit banjir rancangan pada objek penelitian dengan metode HSS Nakayasu dan data banjir kiriman dari DAS Tallo dan DAS Jeneberang ditunjukkan pada Tabel 3.

Tabel 3. Data Debit Banjir

\begin{tabular}{lcccc}
\hline Nama DAS & $\begin{array}{c}\text { Debit banjir puncak } \\
(\mathrm{T}=20 \text { Tahun })\end{array}$ & $\begin{array}{c}\text { Waktu untuk } \\
\text { mencapai debit } \\
\text { puncak }\end{array}$ & $\begin{array}{c}\text { Banjir } \\
\text { kiriman }\end{array}$ & Total \\
\cline { 2 - 5 } & $(\mathrm{m} 3 /$ det $)$ & $($ jam $)$ & $(\mathrm{m} 3 /$ det $)$ & $(\mathrm{m} 3 /$ det $)$ \\
\hline DAS Tallo & 157,19 & 2,00 & 70,15 & 227,34 \\
DAS Tabaringan & 29,54 & 0,61 & 0,00 & 29,54 \\
DAS Jeneberang & 55,33 & 1,05 & 129,06 & 184,39 \\
Sistem Drainase & 86,73 & 0,67 & 0,00 & 86,73 \\
\hline
\end{tabular}

Berdasarkan Tabel 3, maka volume air yang menggenang pada objek penelitian ditunjukkan pada Gambar 5.

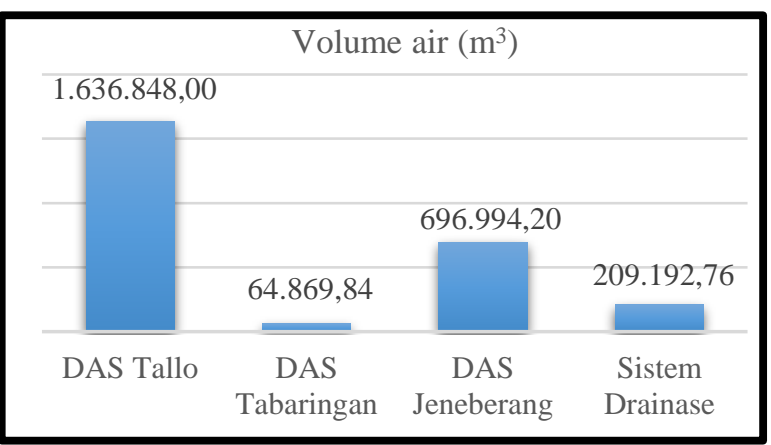

Gambar 5. Volume Air ( $\left.\mathrm{m}^{3}\right)$ 


\section{Model Spasial Level Dasar Bangunan}

Model spasial yang dihasilkan adalah peta beratribut koordinat geografi $\mathrm{x}, \mathrm{y}, \mathrm{z}$ yang berfungsi sebagai instrumen spasial untuk menentukan level dasar bangunan (peil) yang aman banjir hingga Tahun 2030. Model dibentuk dengan menggabungkan data kenaikan muka air global, pasang air laut dan volume air (m3), menggunakan aplikasi Global Mapper dan aplikasi SIG berbasis data DEM ALOS PALSAR resolusi spasial 11,25 m. Model ditunjukkan pada Gambar 6.

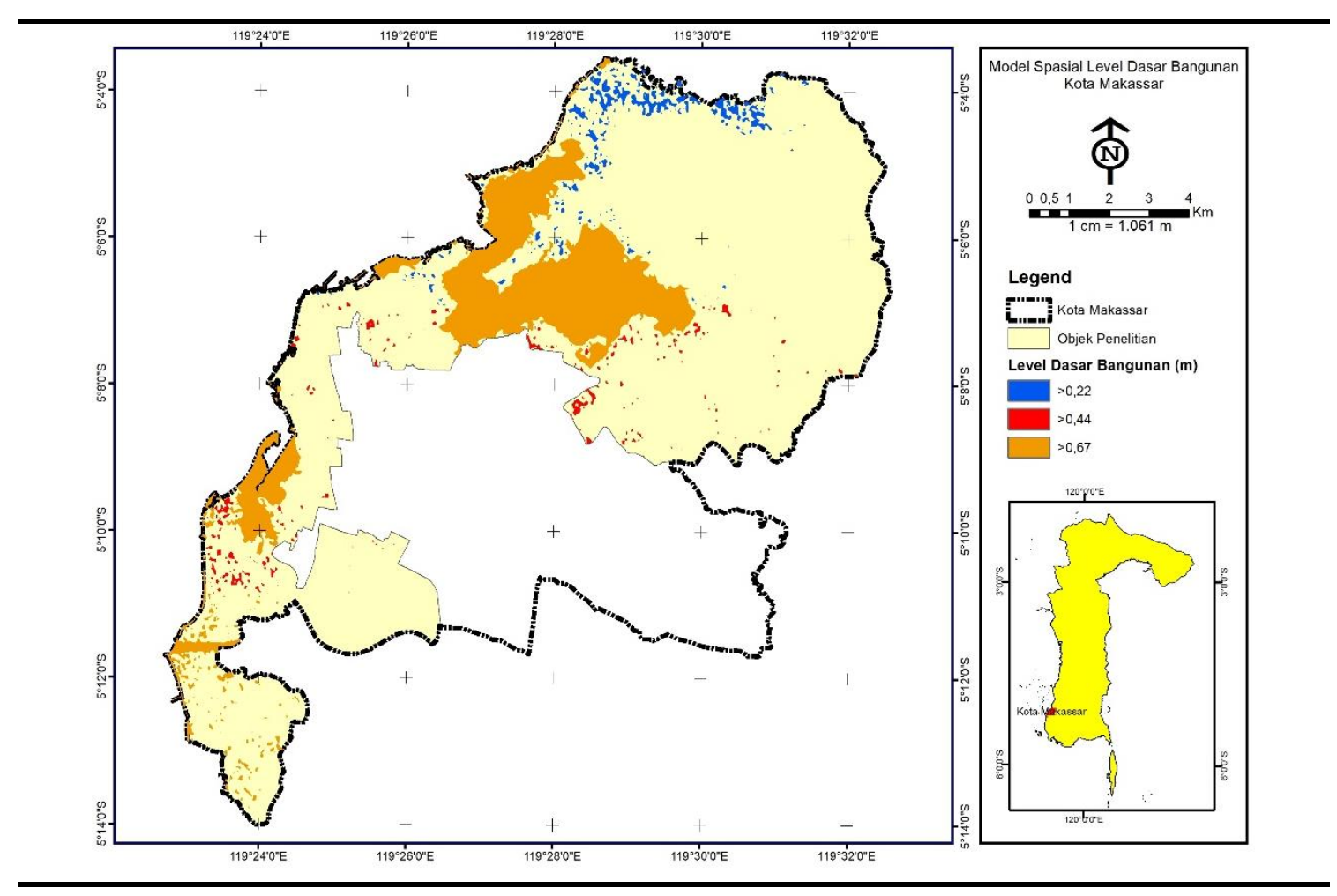

\section{Gambar 6. Model Spasial Level Dasar Bangunan}

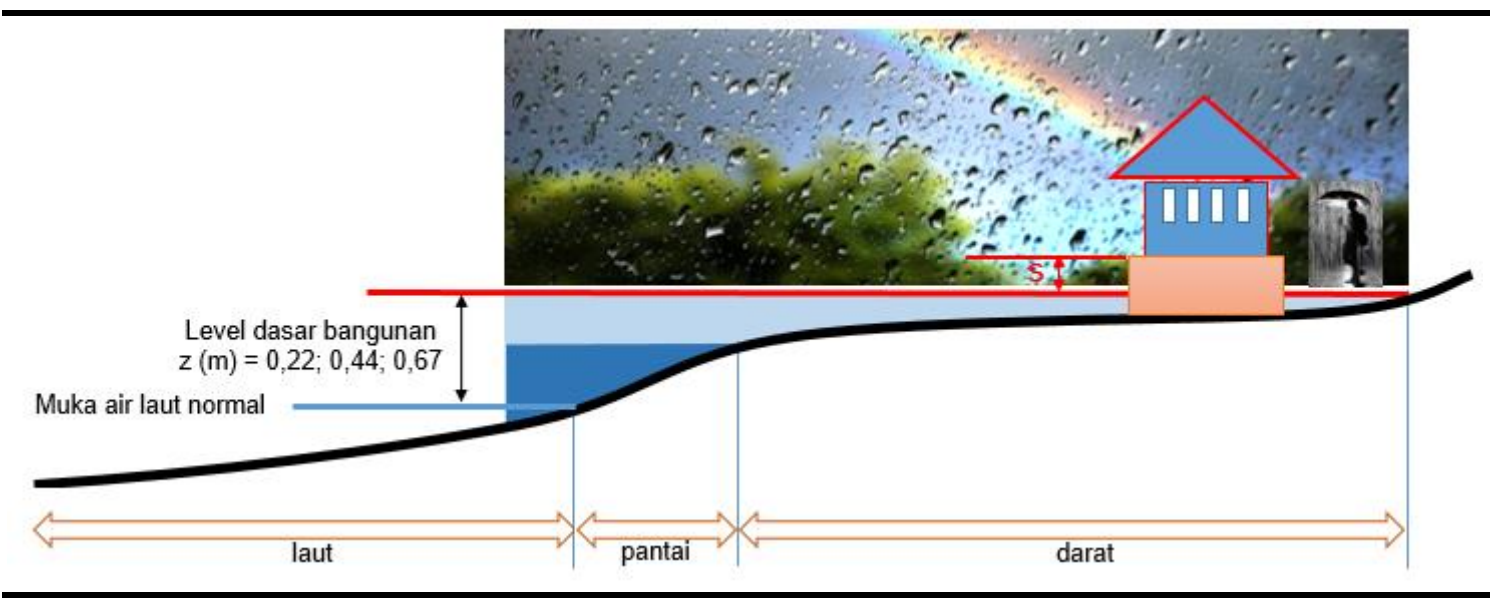

Gambar 7. Profil Melintang Level Dasar Bangunan

Berdasarkan Gambar 6, dapat dinyatakan bahwa level dasar bangunan di Kota Makassar dikelompokkan menjadi 3 zona yaitu zona biru $>0,22 \mathrm{~m}$, zona merah $>0,44 \mathrm{~m}$, 
dan zona orange $>0,67 \mathrm{~m}$. Letak masing-masing zona dapat diidentifikasi berdasarkan koordinat geografi $\mathrm{x}, \mathrm{y}$. Profil melintang model spasial level dasar bangunan ditunjukkan pada Gambar 7.

Model spasial level dasar bangunan dapat disajikan pada skala Kelurahan Buloa, seperti ditunjukkan pada Gambar 8.

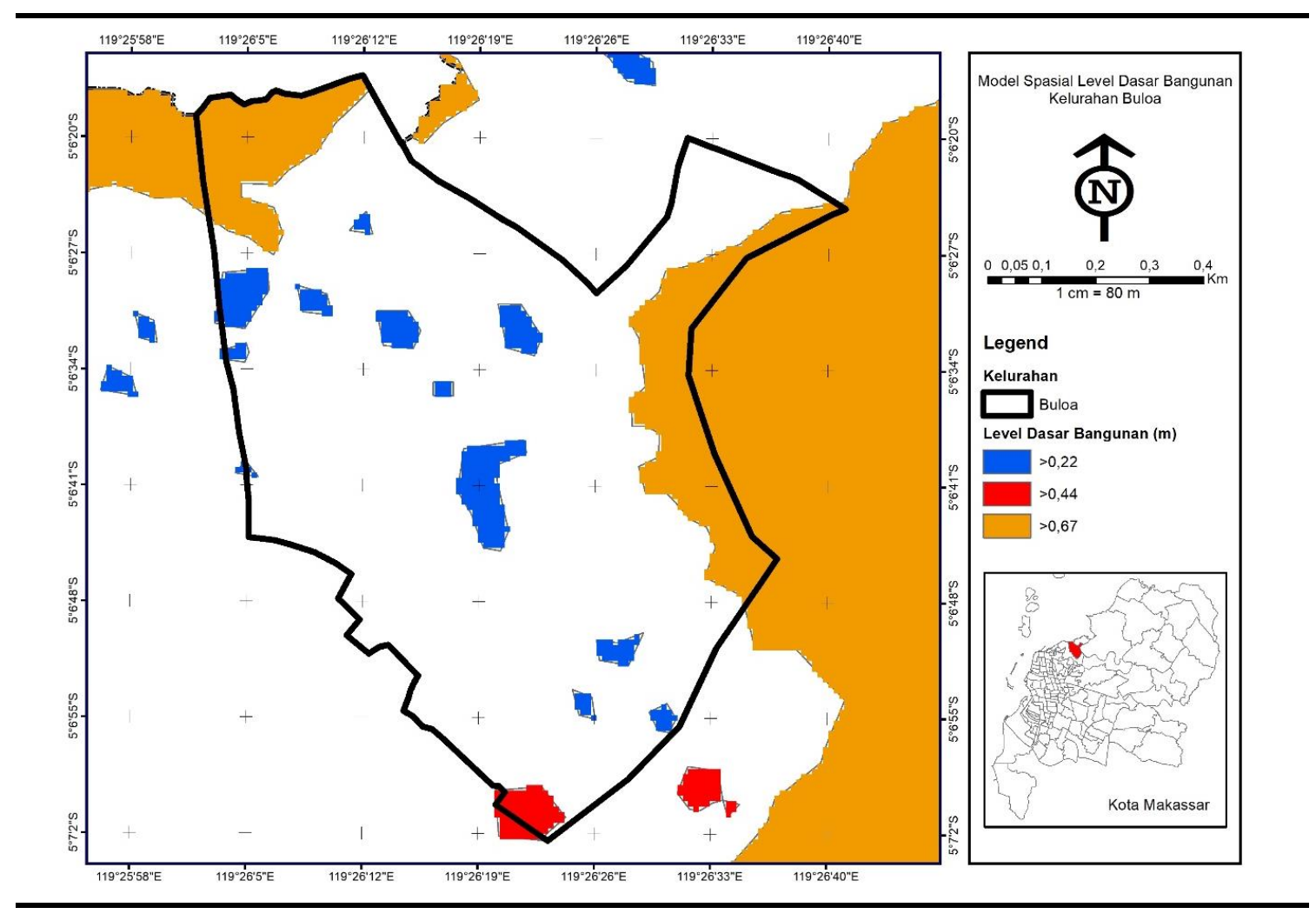

\section{Gambar 8. Level Dasar Bangunan Kelurahan Buloa}

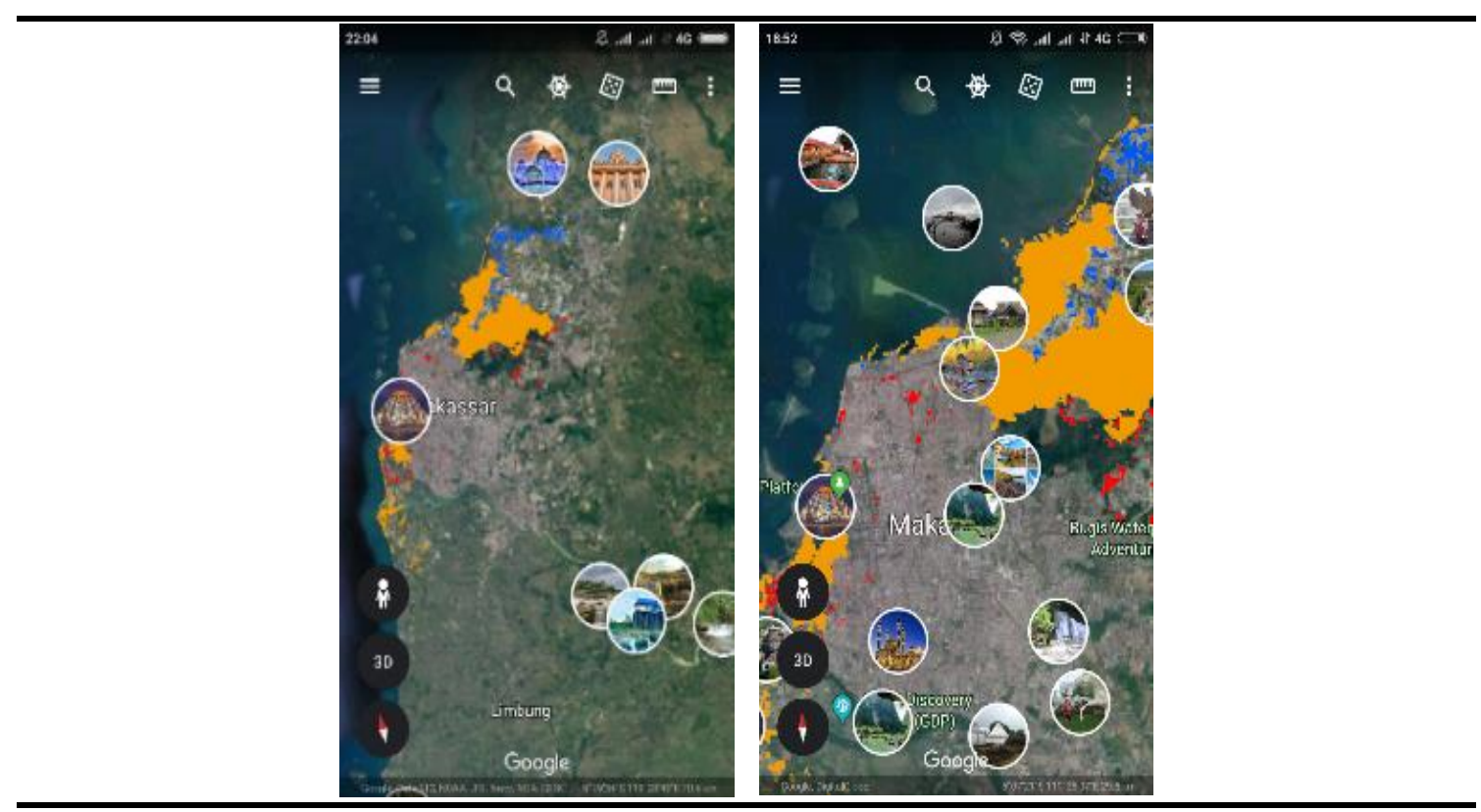

Gambar 9. Aplikasi Model dalam Smartphone 
Keunggulan model karena dapat diakses melalui smartphone, dengan mengaktifkan fitur GPS akan memudahkan untuk membuat keputusan di lapangan. Aplikasi model pada smartphone ditunjukkan pada Gambar 9.

Kota Makassar pada saat hujan dengan intensitas tinggi, pada sebagian wilayah mengalami banjir dan menyebabkan rumah tergenang air, sehingga diperlukan suatu model yang berfungsi sebagai instrumen spasial penentuan level dasar bangunan (peil). Model spasial level dasar bangunan dibangun dengan memperhitungkan variable kenaikan muka air laut global, pasang air laut, banjir aluvial dan banjir kiriman, penggunaan lahan dan tutupan lahan dengan 5 kelas yaitu bisnis, permukiman, hutan, pertanian, dan tubuh air. Penelitian ini belum memperhitungkan variable penurunan tanah.

\section{KESIMPULAN}

Penentuan level dasar bangunan dalam proses desain maupun pelaksanaan (pemasangan boplang) dapat ditentukan dengan merujuk pada model spasial berupa peta yang dilengkapi dengan atribut koordinat geografi $\mathrm{x}, \mathrm{y}, \mathrm{z}$. Variabel penurunan tanah juga penting untuk dianalisis dalam menyusun model spasial level dasar bangunan pada penelitian selanjutnya.

\section{PERNYATAAN RESMI}

Peneliti mengucapkan terima kasih kepada ESRI Indonesia yang turut mendukung pelaksanaan penelitian dengan bantuan software berbasis sistem informasi geografis (SIG) versi 10.5 .

\section{DAFTAR PUSTAKA}

Aurdin. (2014). Pengaruh Perubahan Tata Guna Lahan Terhadap Karakteristik Hidrograf Banjir (Studi Kasus DAS Dengkeng dan DAS Jlantah Bagian Hulu Bengawan Solo Kabupaten Sukoharjo, Provinsi Jawa Tengah). Tekno Global, III(1).

Darhamsyah. (2015). Ketersediaan Air dan Arahan Pengendalian Pembangunan di Kawasan Strategis Nasional MAMMINASATA. Makassar.

Dewi, Limantara, S. (2016). Analisis Parameter Alfa Hidrograf Satuan Sintetik Nakayasu di SUB DAS Lesti. Teknik Pengairan, 7, 107-116.

Fachri, F. J. (2017). Analisis Hidrograf Sungai dengan Menggunakan HSS di Daerah Aliran Sungai Jeneberang Kabupaten Gowa. Universitas Hasanuddin.

Frick, H. (1980). Ilmu Konstruksi Bangunan 1 (17th ed.). Yogyakarta: Kanisius.

Gaitan, S., van de Giesen, N. C., \& ten Veldhuis, J. A. E. (2016). Can urban pluvial flooding be predicted by open spatial data and weather data? Environmental Modelling and Software, 85, 156-171. https://doi.org/10.1016/j.envsoft.2016.08.007

Ghoneem, M. Y. M. (2016). Planning for Climate Change, Why does it Matter? (From Phenomenon to Integrative Action Plan). Procedia - Social and Behavioral Sciences, 216(October 2015), 675-688. https://doi.org/10.1016/j.sbspro.2015.12.060

Imaduddina, S. (2014). Sea Level Rise Flood Zones: Mitigating Floods in Surabaya Coastal Area. Procedia - Social and Behavioral Sciences, 135, 123-129. https://doi.org/10.1016/j.sbspro.2014.07.335

Joesidawati, M. I. (2006). Pemodelan Perubahan Iklim Daerah Kabupaten Tuban Menggunakan MAGICC/SCENGEN, 1-7.

Kodoatie, R. J. (2010). Tata Ruang Air. Yogyakarta: Andi Yogyakarta.

Nganro, Trisutomo, Barkey, A. (2019). Analisis Koefisien Limpasan Permukaan Kota Makassar dengan Metode Cook. TATALOKA, 21.

Ngo-Duc, T. (2014). Climate Change in the Coastal Regions of Vietnam. Coastal Disasters and Climate Change in Vietnam. Elsevier Inc. https://doi.org/10.1016/B978-0-12-800007-6.00008-3

Pudjiharta. (2008). PENGARUH PENGELOLAAN HUTAN PADA HIDROLOGI (Influences of Forest Management on Hydrology)*) Oleh/ By : A. Pudjiharta. Info Hutan, V(2), 141-150. 
Qoriaulfa, Putri, Fadhillah, Harsanto, I. (2016). Analisis Limpasan Langsung Menggunakan Metode Nakayasu, SCS, dan ITB Studi Kasus Sub DAS Progo Hulu. In Simposium Nasional Teknologi Terapan (SNTT) 42016 (pp. 572-580).

Rachmat, P. (2014). Faktor-Faktor Kerentanan yang Berpengaruh Terhadap Bencana Banjir di Kecamatan Manggala Kota Makassar. Jurnal Teknik Pomits, 3(2), 3-8.

Raharjo, S. (2011). Proyeksi Perubahan Iklim Indonesia Menggunakan Model MAGICC-SCENGEN (Studi Kasus Temperatur dan Curah Hujan di Propinsi Papua Barat), 1-8.

Samaawa, H. (2016). Estimasi Debit Puncak Berdasarkan Beberapa Metode Penentuan Koefisien Limpasan di Sub DAS Kedung Gong, Kabupaten Kulonprogo, Yogyakarta. Jurnal Bumi Indonesia, 5.

Shrestha, S., \& Lohpaisankrit, W. (2016). Flood hazard assessment under climate change scenarios in the Yang River Basin, Thailand. International Journal of Sustainable Built Environment, (October). https://doi.org/10.1016/j.ijsbe.2016.09.006

Subarkah, I. (1980). Hidrologi Untuk Perencanaan Bangunan Air (Cetakan Ke). Bandung: Angkasa Offset.

Sudirman, Trisutomo, Barkey, A. (2017). Faktor-Faktor Yang Mempengaruhi Banjir/Genangan di Kota Pantai dan Implikasinya Terhadap Kawasan Tepian Air. In Membingkai Multikultur Dalam Kearifan Lokal Melalui Perencanaan Wilayah dan Kota (p. 141). Denpasar: Program Studi Perencanaan Wilayah dan Kota Universitas Hindu Indonesia. $\quad$ Retrieved from http://digilib.mercubuana.ac.id/manager/t!@file_artikel_abstrak/Isi_Artikel_738864936004.pdf

Sudirman, Trisutomo, Barkey, A. (2018). Watershed identification and its effect toward flood (Case study: Makassar City). International Journal of Advanced Research (IJAR), 6(5), 513-519.

Suhelmi, P. (2014). Model Spasial Dinamik Genangan Akibat Kenaikan Muka Air Laut Di Pesisir Semarang ( Spatial Dynamic Model of Inundated Area Due to Sea Level Rise at Semarang Coastal Area ) Pusat Penelitian dan Pengembangan Sumberdaya Laut dan Pesisir Badan Penelitian dan. J. Manusia Dan Lingkungan, 21(1), 15-20.

Surya. (2015). The Dynamics of Spatial Structure and Spatial Pattern Changes at the Fringe Area of Makassar City. Indonesian Journal of Geography, 47, 11-19.

Sutirto, D. T. (2014). Gelombang Dan Arus Laut Lepas (Cetakan I). Yogyakarta: Graha Ilmu.

Takeda, K. (1983). Hidrologi Untuk Pengairan. (S. Sosrodarsono, Ed.). Jakarta.

Triatmodjo, B. (2013). Hidrologi Terapan (Ketiga). Yogyakarta: Beta Offset Yogyakarta.

Vellinga, K. (1993). Climate change, sea level rise and integrated coastal zone management: An IPCC approach. Ocean \& Coastal Management, 21(1), 245-268. https://doi.org/10.1016/0964-5691(93)90029-X

Wahyuningrum, P. (2007). Aplikasi Sistem Informasi Geografis Untuk Perhitungan Koefisien Aliran Permukaan di Sub DAS Ngunut I, Jawa Tengah. Penelitian Hutan Dan Konservasi Alam, No. 6, 561-571.

Welde, G. (2017). Effect of Land Use Land Cover Dynamics on Hydrological Response of Watershed : Case Study of Tekeze Dam Watershed, Northern Ethiopia. International Soil and Water Conservation Research. https://doi.org/10.1016/j.iswcr.2017.03.002 